\title{
Factors affecting cyberloafing in computer laboratory teaching settings
}

\author{
Sacip Toker ${ }^{1 *+}$ and Meltem Huri Baturay ${ }^{2+}$
}

\author{
*Correspondence: \\ sacip.toker@atilim.edu.tr \\ ${ }^{\dagger}$ Sacip Toker and MeltemHuri \\ Baturay contributed equally \\ to this work \\ ${ }^{1}$ Information Systems \\ Engineering Department, \\ School of Engineering, Atilim \\ University, Kizilcasar Mah., \\ Golbasi, Ankara, Turkey \\ Full list of author information \\ is available at the end of the \\ article
}

\begin{abstract}
This correlational study investigated the factors affecting cyberloafing behavior in an educational environment, specifically that of a computer laboratory teaching setting. A total of 272 students selected using convenience sampling responded to a questionnaire that collected data about cyberloafing behavior and student demographics, personality type, sense of belonging, motivation, locus of control and teacher evaluation (respect, activities, communication, motivation) as well as computer lab teaching settings and norms. The results indicated that students in computer lab teaching settings cyberloaf mainly for socialization, followed by personal business and news follow-up. Males cyberloaf more frequently than females, especially for personal business and news follow-up. As students' internet skills increase, so does their cyberloafing, particularly for personal business and socialization. A lack of instructor norms in computer lab lectures and student amotivation are also associated with increases in cyberloafing for personal business, whereas instructors'respect for students and negative attitudes towards cyberloafing are associated with decreases in cyberloafing for socialization. This paper discusses the study findings in detail and makes recommendations for additional research.
\end{abstract}

Keywords: Cyberloafing, Internet use skills, Instructors' norms and respect,

Amotivation, Attitude towards cyberloafing, Computer laboratory teaching settings

\section{Introduction}

In today's digital era, access to the internet is available to almost everyone, everywhere, whether at home, at work, or at school. Despite the enormous benefits that internet technology offers in terms of learning, the 'inadvisable, excessive and uncontrolled use' of this platform can be harmful (Yllmaz et al., 2015). Cyberloafing is one of the terms used to describe the disruptive behavior of frequent internet usage for personal, non-work-related activities during working hours, often under the guise of doing actual work (Blanchard \& Henle, 2008; Lim, 2002), and for non-academic purposes during course hours (Kalaycl, 2010). Such counterproductive behaviors (Dursun et al., 2018; Lim, 2002) include visiting news and discussion sites, socialnetworking platforms and other virtual communities; checking e-mails; downloading files, including music; online gaming/gambling; and online shopping (Yllmaz \& Yurdugül, 2018). Cyberloafing has been observed both at work and in school classrooms,

C The Author(s) 2021. Open Access This article is licensed under a Creative Commons Attribution 4.0 International License, which permits use, sharing, adaptation, distribution and reproduction in any medium or format, as long as you give appropriate credit to the original author(s) and the source, provide a link to the Creative Commons licence, and indicate if changes were made. The images or other third party material in this article are included in the article's Creative Commons licence, unless indicated otherwise in a credit line to the material. If material is not included in the article's Creative Commons licence and your intended use is not permitted by statutory regulation or exceeds the permitted use, you will need to obtain permission directly from the copyright holder. To view a copy of this licence, visit http:// creativecommons.org/licenses/by/4.0/. 
including computer laboratory teaching settings, where students cyberloaf while they perform tasks or listen to their instructors.

Numerous studies have reported on the increases in student motivation and achievement observed in connection with the use of technology in the classroom (Anwaruddin, 2013; Estapa, \& Nadolny, 2015; Kalanzadeh et al., 2014; Mackinnon \& Vibert, 2002). While schools cannot ignore the opportunities that digital tools provide for enhancing the learning experience (Tindell \& Bohlander, 2012), particularly among today's tech-savvy younger generation, studies have also pinpointed certain adverse effects that accompany the use of technology in the classroom. Computers have been cited as a source of distraction (Fried, 2008) that leads to increases in cyberloafing (Yılmaz et al., 2015) and decreases in learner engagement in connection with increases in opportunities to engage in non-education-related, off-task personal activities (Sivrikova et al., 2019; Skolnik \& Puzo, 2008). Not only does multitasking during lessons pose a threat to comprehension (Sana et al., 2013) and lead to impaired learning on the part of the cyberloafer (Ravizza et al., 2013), classmates and teachers also suffer from decreased motivation and distraction as a result (Akgün, 2020). When compared to regular classrooms, students seem to feel freer to cyberloaf in computer laboratories, and they tend to do so even when they have assignments to complete (Yaşar \& Yurdugül, 2013). University students have been found to cyberloaf not only with their computers, but with their mobile phones as well (Yllmaz et al., 2015). They often multi-task while studying, using their mobile phones, tablets, laptops, or desktop PCs. Worryingly, the extent of cyberloafing is expected to increase as the number of high-tech mobile devices and opportunities for online connectivity increase and more courses start to require mobile devices and computers (Akbulut et al., 2016).

While the literature includes many studies on cyberloafing in a work environment, the number of published studies on cyberloafing in an educational setting, particularly in a classroom where computers are easily accessible, are relatively limited. In a recent study conducted by Varol and Yildirım (2019), four factors were found to have an influence on cyberloafing in a school setting, namely (a) the instructor (i.e., instructional methods, material usage, content knowledge and communication skills), (b) course content relevance, student attentiveness and motivation levels, and (c) the learning environment (i.e., classroom seating, lighting and temperature).

The current study investigates the demographic, psychological and academic factors affecting cyberloafing in computer laboratory teaching settings in light of Van Doorn's (2011) theoretical framework described below. The following research questions were formulated accordingly:

1. Do students cyberloaf during their computer laboratory classes? If so, what types of cyberloafing activities do they engage in, and to what extent?

2. Are any of the following predictive of the overall cyberloafing activities identified in the first research question?

a. student demographic factors (gender, internet skills, internet experience, and internet use frequency), 
b. student-related individual factors (personality, internal-external locus of control, sense of belonging, attitude towards cyberloafing),

c. organizational factors (classroom norms, instructor respect for students),

d. loafing activities.

3. Are any of the above-mentioned factors predictive of the specific types of cyberloafing activities identified in the first research question?

\section{Theoretical framework}

Van Doorn (2011) offers the only available theoretical framework for cyberloafing. He describes the phenomenon in an organizational setting as a multidimensional construct consisting of different types of activities and behaviors and influenced by organizational policies, the relationship between job demands and resources, additional work and family responsibilities, and individual personalities. Li and Chung (2006) identify four main types of cyberloafing activities: social, which includes both self-expression (e.g., Facebook, Twitter, Instagram) and information-sharing (e.g. Blogger.); informational (e.g., internet searches); leisure (e.g., online gaming, downloading music, downloading software); and virtual emotional activity (e.g., online shopping, dating sites and other unclassifiable activities). Cyberloafing behavior, on the other hand, describes cyberloafing in terms of its consequences, either positive or negative. Positive behaviors include cyberloafing for development, i.e., as a source of learning and skill improvement (Belanger \& Van Slyke, 2002) and for recovery, i.e., as a means of reducing discomfort and positively impacting on individual health (Lim \& Chen, 2012; McLean et al., 2001), whereas negative behaviors include deviant behavior that reduces productivity (Weatherbee, 2010) and addictive behavior (Young, 2010), i.e., behavior that is problematic and habitual.

Studies of cyberloafing in the workplace have examined how organizational policies related to internet availability, work hours and use of one's own device at work may impact cyberloafing either positively or negatively. With regards to whether or not policies limiting employee usage of the internet are effective in preventing cyberloafing, the results are inconclusive (e.g., Blanchard \& Henle, 2008; Lim \& Teo, 2005). Lim et al., (2002) and Anandajaran and Simmer (2004) emphasize that both organizational control and individual responsibility play a role in dictating cyberloafing behaviors. The recent trend of allowing/expecting employees to use their own devices for work as part of an effort to reduce organizational expenses on technological infrastructure is a question addressed by Van Doorn (2011), who suggests that employees may be more likely to engage in increased cyberloafing when they use their own devices, as this makes it easier to access personal sites and links. Flexibility in terms of work hours and location represents another emerging trend that may trigger cyberloafing. As Kurland and Bailey (1999) point out, flexible work schedules characterized by a lack of supervision and monitoring may increase the tendency of employees to cyberloaf, especially, when they are not sufficiently informed about the rules.

The relationship between job demands and resources has also been put forward as having a role in cyberloafing behavior (Van Doorn, 2011). Job demands are defined as the work-related stimuli requiring cognitive, emotional and/or physical effort (Jones \& 
Fletcher, 1996), whereas job resources describe the factors that make it possible to deal with these demands (Hobfoll, 2001). The Demand-Induced Strain Compensation (DISC) model describes job demands and resources in terms of their cognitive, emotional and physical aspects (De Jonge \& Dormann, 2006) and suggests that high demands combined with high resources result in active learning and growth in the workplace. By contrast, cyberloafing has reported to be one consequence of a lack of balance between job demands and resources (Henle \& Blanchard, 2008; Lim, 2002; Robinson \& Bennett, 1995). Specifically, low demand and high resources prompt employees to search for non-work-related activities to kill time when they have no tasks to complete, whereas in cases of high demand and low resources, employees engage in cyberloafing as a form of deviant behavior, either as a means of escape, which carries the potential of addiction (LaRose et al., 2010), or to replenish their resources, which carries the potential of recovery (Weatherbee, 2010). Janssen et al. (2004) noted a connection between high psychological job demands and a lack of balance between work and family, suggesting an interaction between these two factors could lead to cyberloafing, either directly or indirectly.

The "Five Factor "Theory provides a comprehensive explanation of personality traits in terms of five basic dimensions: neuroticism, openness to experience, conscientiousness, extraversion, and agreeableness (Bacanlı et al., 2009; Costa, \& McCrae, 2011). These dimensions have been suggested as forming the basis of human personality and encompassing the characteristics of human thought, emotion and behavior. While they might manifest in different degrees, all people share the same basic traits regardless of gender, age or culture, (Novikova, 2013). Van Doorn (2011) theorizes the expected relationships between personality traits and cyberloafing based on the relationships identified for internet usage. According to Landers and Lounsbury (2006), neuroticism and openness to experience are unrelated to internet usage, whereas agreeableness, conscientiousness and extraversion are correlated with less frequent usage. Wyatt and Phillips (2005) infer that less agreeable and more introverted individuals are more frequent users of the internet, which represents less of a distraction for more conscientious people.

\section{Literature review}

In its effort to identify the factors affecting cyberloafing in educational settings, particularly computer laboratory teaching situations, the current study is grounded mainly in Van Doorn's (2011) theoretical framework. However, rather than workplace policies and work-related factors, the construct of instructor norms is examined, together with instructor respect and student amotivation. The potential impact of personality is also included in the theoretical model developed here, as are sense of belonging, locus of control and gender, along with internet skills and attitudes towards cyberloafing and loafing. In total, 11 factors and their relationships with cyberloafing are examined, with each factor explained briefly below.

\section{Instructor norms}

The Theory of Reasoned Action suggests that subjective norms and attitudes towards a behavior are predictors of behavioral intention (Ajzen, 1991), which then triggers the actual behavior of an individual. Lim (2002) demonstrated subjective norms to be a 
determinant of employee cyberloafing, and Blanchard and Henle (2008) demonstrated more specifically that supervisor norms are positively related to minor cyberloafing (e.g., personal use of e-mail and the internet) in the working environment, although they found no relationship between supervisor norms and major cyberloafing (e.g., gambling, chatting, downloading music, visiting adult websites, reading blogs). Based on this finding, it may be suggested that instructor norms, which represent a similar type of social pressure in an educational setting, could influence student conformity to rules or prompt deviant behaviors such as cyberloafing. In fact, the literature suggests that cyberloafing in schools may be prevented through classroom management, including instructor communication skills and motivational ability (Dursun et al., 2018), and controlling processes, such as those relating to team members when working on collaborative tasks (Henle et al., 2009). Conversely, behaviors such as monitoring, rulemaking and punishment can have a negative effect on individuals. For example, de Lara et al. (2006) found cyberloafing and punishment to be positively correlated, and Lim (2002) found that employees who perceived an imbalance in their relationship with their employer were more likely to engage in cyberloafing and other deviant behavior.

\section{Computer laboratory teaching settings}

The use of computers for educational purposes in developed countries began in the 1960s at the university level and in the 1970s at the secondary school level. Computers also entered into educational use at the university level in Turkey in the 1960s, although it was not until the mid-1980s that computers were exploited for educational purposes in high schools (Keser \& Teker, 2011). At this time, computer laboratories were established in educational settings in order to allow students more time to practice coding and programming, as well as the opportunity to study English, math, geography and other subjects. Many studies have reported computers to increase student interest and motivation (Shi \& Bichelmeyer, 2007), which explains their popularity in K12 as well as university settings. However, according to Yaşar and Yurdugül (2013), students tend to take advantage of internet access in computer laboratory teaching settings for personal rather than educational reasons, and a number of studies (Brubaker, 2006; Kalayc1, 2010) have reported that students engage in deviant behavior, including cyberloafing, in computer classes. In addition, Saritepeci (2019) found that student cyberloafing behavior can be significantly affected by unauthorized access to a school's network.

\section{Instructor respect}

As members of the millennial generation, today's students are 'digital natives' (Prensky \& Berry, 2001) so intimately familiar with digital devices that they treat them like bodily appendages, unable or unwilling to part with them anytime, anywhere. The noneducational use of digital technologies in the classroom often creates conflict between students and their instructors. Understandably, school administrators are continuously looking for ways to decrease cyberloafing in the classroom. Gerow et al. (2010) have found that monitoring on the part of instructors leads to reduction in student cyberloafing in the classroom. Conversely, Yllmaz and Yurdugül (2018) found that the psychosocial environment of the classroom-including teacher support (instructor respect), involvement, investigation, task orientation, cooperation and equity—can affect student 
cyberloafing behavior. Educating students on class ethics has also been suggested as a way to decrease cyberloafing (Soh et al., 2018).

\section{Amotivation level}

Amotivation, briefly, can be described as the "absence of motivation", the most important factor to affect learner performance and behavior (Pintrich \& De Groot, 1990). The construct, found in self-determination theory (Deci \& Ryan, 2002), describes a psychological state in which individuals cannot identify an association between their behavior and the outcome of that behavior. Amotivated and demotivated students harbor little or no reason to engage in classroom learning activities. This motivational deficit has been found to be strongly associated with maladaptive functioning (Cheon, \& Reeve, 2015) and a lack of belief in the capacity to perform an activity (Legault et al., 2006).

Classroom boredom, inadequate concentration in class, and psychological stress have also been associated with student amotivation (Vallerand et al., 1992), as have factors such as perceived home-school dissonance and unfavorable student-teacher relationships (Deci \& Ryan, 2002). Moreover, amotivation has been shown to be a significant mediator of associations between home-school dissonance, classroom disruptive behavior, and academic cheating (Brown-Wright et al., 2013). While an increase in student motivation is associated with more active and successful learning processes (Zandvliet \& Fraser, 2005), a lack of motivation engenders deviant behaviors such as cyberloafing (Yllmaz \& Yurdugül, 2018). According to Durak (2019), motivation levels negatively predict cyberloafing behavior in courses where students are able to access social networking sites.

\section{Personality traits}

Personality traits are general tendencies and genetic 'enduring dispositions' (Loehlin, 1992) that are distinct from abilities (Costa et al., 1995). The Five Factor Theory defines five basic dimensions of personality: neuroticism, openness to experience, conscientiousness, extraversion, and agreeableness (Bacanlı et al., 2009). The theory has been used as a framework for examining the associations between personality and a variety of phenomena, such as social networking site usage and addictive tendencies (Wilson et al., 2010), workplace deviance (Hastings \& O'Neill, 2009), academic performance (Poropat, 2009), teacher burnout (Cano-García et al., 2005), emotional intelligence (Pishghadam \& Sahebjam, 2012) and cyberloafing (Krishnan et al., 2010; O’Neill et al., 2014; Sheikh et al., 2019; Varghese \& Barber, 2017).

\section{Sense of belonging}

Sense of belonging refers to the degree to which an individual feels accepted, respected, and supported in a community. Sense of belonging has been studied in relation to general school motivation, effort, and expectations of success (Goodenow \& Grady, 1993); gang-related problems (Burnett \& Walz, 1994); student completion rates (Kember et al., 2001); and academic grades and competence, self-worth, internalizing/externalizing behaviors, and parental education (Pittman \& Richmond, 2007), among other phenomena. Individuals who feel a strong sense of belonging to their organization have been found to display less social loafing (Van Dick et al.,Van Dick, Stellmacher, et al., 2009; 
Van Dick, Tissington, et al., 2009) and may even outperform other groups (Van Dick, Tissington, et al., 2009).

\section{Locus of control}

Locus of control provides the framework for Rotter's (1966) Social Learning Theory, which states that individual performance is based on their behavioral expectations. Internal locus of control refers to the belief that personal actions influence external events, whereas external locus of control refers to the belief that success and failure are the outcome of external factors beyond one's control. Cüceloğlu (1996) has elaborated on the Social Learning Theory, noting that it involves a value attached to the expected result of a particular behavior; for example, the level of attention students pay to information is related to the degree to which they believe they are responsible for their own academic success (Burger, 2006). Blanchard and Henle (2008) hypothesized an association between external locus of control and both serious and minor cyberloafing at work.

\section{Gender}

The vast majority of studies indicate that in general, males cyberloaf more than females (Baturay \& Toker, 2015; Dursun et al., 2018; Hargittai \& Shafer, 2006; Lim \& Chen, 2012; Saritepeci, 2019; Şenel et al., 2019; Vitak et al., 2011; Yllmaz et al., 2015). When it comes to specific types of cyberloafing, however, various, and somewhat conflicting, gender differences have been reported. For example, Andreassen et al. (2014) found men engage in more social networking, i.e., socialization cyberloafing, during work hours than women, whereas Arabacı (2017) found women engage in more cyberloafing for news follow-up than men. A 2017 study by Akbulut, Dönmez and Dursun reported no gender differences in terms of cyberloafing types with the exception of online gaming/gambling, which was more common among men than women, whereas another study by the same researchers found that males spent more time than females on three types of cyberloafing activities: online gaming/gambling, online shopping, and accessing online content (Dursun et al. 2018).

\section{Internet skill level}

Internet skill levels appear to play a role in the types of cyberloafing undertaken. A study examining the association between cyberloafing and internet skill levels reported that students with advanced- and expert-level internet skills cyberloafed more often than students with intermediate-level skills and novice internet users (Baturay \& Toker, 2015). Moreover, considering the correlation found between skill level and cyberloafing for socialization, the authors suggested that the development of internet skills triggered socialization behavior in students. Arabacı (2017) found individuals with medium and advanced levels of internet skills engaged in significantly more cyberloafing for personal business than other types of cyberloafing, and Blanchard and Henle (2008) reported internet skills to be positively correlated with minor cyberloafing, e.g., use of e-mail for personal reasons. 


\section{Attitude towards cyberloafing}

According to Ajzen (1991) attitude is one of three factors explaining a person's intention to engage in a particular behavior. According to the Theory of Reasoned Action (Ajzen, 1985, 1991; Fishbein \& Ajzen, 1975), both an individual's attitude, i.e., positive or negative opinion regarding a behavior, and subjective norms, i.e., social influence referent to others, contribute to the intention of performing a behavior. In his subsequent theory, the "Theory of Planned Behavior" (1985), Ajzen expanded his model by adding "perceived behavioral control", defined as the feelings, ideas, and behavioral tendencies of individuals towards objects or events that direct behavior and impact on the occurrence of a behavior (Yllmaz \& Yurdugül, 2018). When applied to cyberloafing, it may be said that subjective norms combine with an individual's attitude towards cyberloafing and perceived behavioral control to indirectly contribute to cyberloafing by influencing that individual's intention to cyberloaf, which in turn leads directly to actual cyberloafing (Askew et al., 2011). A study of cyberloafing in the work environment (Liberman et al., 2011) found attitudes towards cyberloafing, along with employee participation in noninternet loafing behavior, to be positively correlated with cyberloafing. In an educational setting, Soh et al. (2018) found that a positive attitude towards cyberloafing is predictive of a student's intention to cyberloaf, which in turn predicts whether they will perform cyberloafing behavior. Attitudes towards computers and computing courses have also been found to significantly affect student cyberloafing behaviors (Yilmaz \& Yurdugül, 2018). Attitudes toward cyberloafing behavior were also found to be significantly associated with perceived societal norms regarding in-class use of cellphones (Knight, 2017).

\section{Loafing}

Loafing, sometimes referred to as "free riding", is a type of deviant and disruptive behavior in educational and work-related settings (Mulvey \& Klein, 1998). Individuals who perform loafing, or "loafers", have been described as "telephone chatters" and "restroomminded, long lunchers", as compared to "cyberloafers", who loaf by using the internet (Lim, 2002). Both behaviors are similar in that they involve spending time on non-educational or non-work-related issues, although, notably, cyberloafing provides camouflage to loafers and makes loafing easier. Van Doorn (2011) found that loafing behavior increases with age, and suggested that age has an effect on cyberloafing as well as other forms of loafing.

\section{Method}

This study was designed as a correlational study (Creswell, 2012) in order to evaluate the relationships among the 11 factors listed above (independent variables) and three types of cyberloafing, i.e., socialization, personal business and news follow-up (dependent variables). Sample size was determined based on purposive and convenience sampling and the requirements for structural equation modelling (SEM). A number of authors (Boomsma, 1985; Kline, 1998) have suggested a minimum or moderate sample size for SEM to range between 100 and 200, while others have recommended 5-10 observations per estimated parameter (Bentler \& Chou, 1987; Bollen, 1989) and 10 cases per variable (Nunnally, 1967). Power analysis conducted prior to data collection for this 
study indicated that between 245 ( 0.80 power) and 493 participants ( 0.99 power) were required for SEM (MacCallum et al., 1996). Therefore, data collection was halted when 272 participants were reached (SEM: 0.847 power, $\mathrm{df}=8, \mathrm{RMSEA}-\mathrm{H} 0=0.10$ (mis-fit), and RMSEA-H1 $=0.030$ (good-fit), $\mathrm{p}=0.05$ ).

\section{Study participants}

A total of 272 students at a university in Turkey voluntarily participated in the study. All participants had at least one social-networking account and had completed a mandatory computer literacy course in a computer laboratory classroom. After receiving a brief explanation of the study purpose, participants were asked to complete a questionnaire (see below, "Measurement tools" section).

Demographic characteristics of the participants, including gender and information on internet usage, are given in Table 1. Of the 272 participants, 122 (44.9\%) were male, and 150 were female (55.1\%). The average age of participants was 20.95 years $(\mathrm{SD}=1.55)$. Mean overall GPA of participants and mean grade in the computer literacy course referenced for cyberloafing behavior were $2.91(\mathrm{SD}=0.46)$ and 71.24 $(\mathrm{SD}=15.64)$, respectively. Most participants $(60.3 \%)$ rated their internet skills as "intermediate". More than $85 \%$ of participants $(n=239,87.9 \%)$ stated that they used the internet on a daily basis, and the remaining participants $(n=33,12.1 \%)$ stated that they used the internet either weekly or monthly. Whereas $77.9 \%$ of participants $(n=212)$ said they had an average to high level of experience using the internet, the remaining $22.1 \%(n=60)$ said they had little to no experience.

Table 1 Study participants

\begin{tabular}{lrr}
\hline & $F$ & $\%$ \\
\hline Gender & 150 & 55.1 \\
Female & 122 & 44.9 \\
Male & & \\
Internet skill level & 27 & 9.9 \\
Beginner & 164 & 60.3 \\
Intermediate & 68 & 25.0 \\
Advanced & 13 & 4.8 \\
Expert & & \\
Internet experience & 11 & 4.0 \\
No experience & 49 & 18.0 \\
Low level & 129 & 47.4 \\
Average level & 58 & 21.3 \\
High level & 25 & 9.2 \\
Very high level & & \\
Frequency of internet usage & 219 & 80.5 \\
Daily-several times & 20 & 7.4 \\
Daily-once & 21 & 7.7 \\
Weekly-several times & 5 & 1.8 \\
Weekly-once & 4 & 1.5 \\
Monthly-several times & 3 & 1.1 \\
Monthly-once & & \\
\hline
\end{tabular}




\section{Measurement tools}

Data was collected using a questionnaire that was self-implemented by participating students in a computer laboratory course during the 2019-2020 Fall semester. The questionnaire was comprised of the following:

\section{Demographic information (11 items)}

This section collected information on gender and internet skill, experience, and frequency of usage in order to determine the impact of these factors on cyberloafing.

\section{Adjective Based Personality Scale (ABPT) (40 items)}

The ABPT was developed by Bacanlı et al. (2009) to measure personality. It is based on instruments used to measure the Big Five personality traits used by psychologists to describe human personality (Costa \& McCrae, 1992; Goldberg, 1993). Construct validity of the ABPT was demonstrated by oblimin rotation factor analysis. The ABPT also demonstrated concurrent validity with the Sociotropy-Autonomy Scale, which measures such things as separation anxiety, efforts to satisfy others, and disapproval in relationships (Beck et al., 1988; Savaşır \& Şahin, 1997); Reactions to Conflicts (Demirci, 2004); Positive and Negative Affect Schedule (PANAS) (Gençöz, 2000; Watson et al., 1988); and State-Trait Anxiety Inventory (STAI) (Öner \& ve Le Compte, 1998; Spielberger, 2010). Test-retest reliability and Cronbach's $\alpha$ for internal consistency indicated the ABPT to have satisfactory psychometric properties and to be suitable for assessing personality traits of undergraduate and graduate students.

\section{Cyberloafing (12 items)}

This scale was originally developed by Blanchard and Henle (2008) and adapted to Turkish by Kalaycı (2010). The original instrument included minor and major cyberloafing behaviors as two sub-factors, and applied explanatory factor analysis only. In the Turkish version, both explanatory and second-order confirmatory factor analyses indicated a three-factor scale comprised of personal business, socialization and news follow-up subscales, with reliability measures of $0.83,0.85$, and 0.66 , respectively, whereas the overall reliability of the scale was 0.88 .

\section{Sense of belonging to the department (4 items)}

This scale measured the extent to which participants felt they belonged to the department in which they were studying. Construct validity was determined using EFA [KMO Measure of Sampling Adequacy (0.647); Bartlett's Test of Sphericity $\left(\chi^{2}(6)=453.269\right.$, $\mathrm{p}<0.01)$ ]. EFA communalities ranged between 0.504-0.721. A single factor explained 62.09 percent of total variance, with item loading ranging between $0.710-0.849$, and a Cronbach's $\alpha$ of 0.792 .

\section{Attitudes towards cyberloafing (3 items)}

This scale measured participant attitudes towards cyberloafing. EFA was used for construct validity [KMO Measure of Sampling Adequacy (0.702); Bartlett's Test of 
Sphericity $\left.\left(\mathrm{X}^{2}(3)=368.755, \mathrm{p}<0.01\right)\right]$. EFA communalities ranged between $0.734-0.838$. A single factor explained $77.13 \%$ of total variance, with item loadings ranging between $0.857-0.915$, and a Cronbach's $\alpha$ of 0.851 .

\section{Loafing (4 items)}

This scale measured the daily loafing behavior of participants. EFA was used for construct validity [KMO Measure of Sampling Adequacy (0.656); Bartlett's Test of Sphericity $\left.\chi^{2}(6)=147.854, \mathrm{p}<0.01\right)$ ]. EFA communalities ranged between 0.294-0.614, indicating good fit to data. A single factor explained 48.33 percent of total variance, with item loadings ranging between $0.543-0.783$. A Cronbach's $\alpha$ of 0.631 indicated satisfactory internal consistency.

\section{Computer lab teaching settings ( 9 items)}

This scale measured participant perceptions of factors related to computer lab teaching settings. EFA was used for construct validity [KMO Measure of Sampling Adequacy (0.703); Bartlett's Test of Sphericity $\left.\chi^{2}(36)=247.038, p<0.01\right)$ ], with communalities ranging between $0.307-0.592$. Three factors - computer lab teaching settings, instructor responsibility, instructor monitoring of students during class-explained 51.89 percent of total variance. Item loadings for these factors ranged between $0.410-0.742,0.634-$ 0.749 and $0.491-0.700$, respectively. The scale had a Cronbach's $\alpha$ of 0.422 , indicating moderate internal consistency.

\section{Norms for cyberloafing (6 items)}

This scale measured peer group and instructor norms related to cyberloafing. EFA was used for construct validity [KMO Measure of Sampling Adequacy (0.817) Bartlett's Test of Sphericity $\left(\mathrm{X}^{2}(15)=774.528, \mathrm{p}<0.01\right)$ ], with communalities ranging between 0.719 0.805. Two factors-peer norms and instructor norms-accounted for 76.15 percent of total variance. Item loadings for the factors ranged between $0.854-0.857$ and $0.862-$ 0.908 , respectively. The scale had a Cronbach's $\alpha$ of 0.857 , indicating satisfactory internal consistency. Lower scores on the scale indicate little presence of either instructor or peer-group norms.

\section{Teacher evaluation (15 items)}

This scale measured student evaluations of their instructors in computer literacy courses. EFA was used for construct validity [KMO MSA 0.818; Bartlett's Sphericity $\left(x^{2}\right.$ $(78)=800.761, \mathrm{p}<0.01)$ ], with communalities ranging between 0.499-0.662. Four factors-respect, activities, communication, and motivation-accounted for 58.97 percent of total variance, with item loadings ranging between $0.709-0.811$ (respect), $0.553-0.807$ (activities), 0.606-0.758 (communication) and 0.592-0.841 (motivation). The scale had a Cronbach's $\alpha$ of 0.831 , indicating a satisfactory level of internal consistency.

\section{Locus of control (29 items)}

The Internal-External Locus of Control scale was originally developed by Rotter (1966). Psychometry and clinical psychology experts reviewed the original version, translating it to Turkish and adjusting it for cultural relevance (Dağ, 1991). Reliability of the Turkish 
version of the scale was estimated by calculating Cronbach's $\alpha$ ( 0.71 for 532 participants), KR-20 (0.68 for 99 participants) and test-retest reliability correlation coefficients $(0.83$ for 99 participants). EFA yielded seven factors (chance control, political external control, chance and interpersonal control, external control on school achievement, external control on interpersonal relationships, fatalism, political and school achievement external control) that explained 47.7 percent of total variance. Concurrent validity with Rosenbaum's Learned Resourcefulness Scale (Rosenbaum, 1980) and Symptoms Checklist (SCL-90-R) was obtained, with correlation coefficients of $0.29(\mathrm{p}<0.001)$ and 0.21 $(\mathrm{p}<0.001)$, respectively.

\section{Scale of motivation in education (Echelle de Motivation en Éducation) (12 items)}

The original scale was developed in French by Vallerand et al. (1992) to measure student motivation in an educational setting. A total of 12 items loaded on four factors that described different types of motivation (intrinsic, integrated, introjected, amotivated). The Turkish version of the scale (Kara, 2008) maintained the original factor structure and accounted for $63.48 \%$ of variance, with factor loading ranging between $0.380-0.750$. Internal consistency reliability Cronbach's $\alpha$ values were 0.84 for the entire scale and between $0.78-0.80$ for the individual factors.

\section{Data analysis}

Questionnaire data was entered into an electronic spreadsheet and transferred to the software programs SPSS 22.0 and AMOS 22.0 for analysis. Descriptive analysis (e.g., frequency, percent, mean, standard deviation) was used to identify the types and extent of student cyberloafing behavior during their computer laboratory classes (Research Question 1). Multiple linear regression analysis was performed using the measures described above as independent variables and general cyberloafing behavior as the dependent variable in order to determine the factors affecting cyberloafing in general (Research Question 2). Assumptions were explored prior to the analysis, and no issues were detected. Structural equation modelling (SEM) analysis was performed using the measures described above as independent variables and personal business, socialization and news follow-up cyberloafing as dependent variables in order to determine the factors affecting the three different types of cyberloafing behavior (Research Question 3).

\section{Results}

Types of cyberloafing in educational settings

Descriptive statistics related to cyberloafing are presented in Table 2. Overall, more than $50 \%$ of participants reported engaging in cyberloafing. The most common type of

Table 2 Types of cyberloafing

\begin{tabular}{lrrrr}
\hline & M & SD & Min & Max \\
\hline Cyberloafing & 34.03 & 9.212 & 13 & 65 \\
Personal business & 12.48 & 5.254 & 6 & 30 \\
News follow-up & 5.76 & 2.110 & 2 & 10 \\
Socialization & 15.80 & 4.540 & 5 & 25 \\
\hline
\end{tabular}


Table 3 Coefficients of factors on cyberloafing

\begin{tabular}{lccr}
\hline \multicolumn{2}{c}{ B } & SE & \multicolumn{1}{c}{ B } \\
\hline Constant & $17.575^{* *}$ & 2.975 & \\
Internet skills & $3.319^{* *}$ & 0.757 & 0.250 \\
Instructor norms & $0.466^{* *}$ & 0.174 & 0.155 \\
Amotivation & $0.456^{* *}$ & 0.174 & 0.149 \\
Instructor respect for students & $-0.698^{*}$ & 0.295 & -0.136 \\
Gender & $2.355^{*}$ & 1.063 & .127 \\
Female (1), Male (2) & & & 0.119 \\
Student attitude towards cyberloafing & $0.340^{*}$ & 0.168 & \\
\hline $\mathrm{N}=272, \mathrm{R}^{2}=17.9 \%$, Adjusted $\mathrm{R}^{2}=16.0 \%$, Dashes indicate no value & & \\
${ }^{*} \mathrm{p}<0.05,{ }^{* *} \mathrm{p}<0.01$ & & &
\end{tabular}

cyberloafing behavior was socialization, reported by $63.2 \%$ of participants, followed by news follow-up (52.6\%) and personal business (41.6\%).

\section{Factors affecting cyberloafing in computer laboratory settings}

A stepwise multiple regression analysis model was created to identify the factors determining cyberloafing behavior (Table 3). The results showed that 6 variables explained 17.9 percent of total variance in cyberloafing behavior $[F(6,265)=9.605, p<0.01]$.

Of all the factors examined, internet skill level had the greatest impact on cyberloafing, followed by gender, instructor respect for students, instructor norms regarding classroom cyberloafing, student amotivation, and student attitude towards cyberloafing.

Cyberloafing behavior scores increased by 3.319 points when students improved their internet skills one level (e.g., moving from beginner to intermediate, or advanced to expert), with other variables constant. Male students demonstrated more frequent cyberloafing behavior than females, with the cyberloafing score of a male student 2.355 points higher than that of a female student with all other variables constant.

Greater instructor respect for students was associated with a decrease in cyberloafing behavior; with all other variables constant, a one-point increase in the score for instructor respect for students resulted in a 0.698-point decrease in student cyberloafing behavior. Conversely, a one-point increase in the score for instructor norms, indicating greater tolerance for behavior unrelated to class activities, was associated with a 0.466 -point increase in student cyberloafing scores.

An increase in student amotivation was also associated with an increase in cyberloafing. With all other variables constant, a one-point increase in student amotivation scores was accompanied by a 0.456-point increase in student cyberloafing behavior scores. Interestingly, although amotivation had an effect on cyberloafing, other motivation types (i.e., introjected, intrinsic, and integrated) did not have a significant impact. Student attitudes towards cyberloafing was also associated with cyberloafing behavior, with more positive attitudes towards cyberloafing accompanied by more cyberloafing behavior. Specifically, with all other variables constant, a one-point increase in the score for attitude towards cyberloafing was accompanied by a 0.340 -point increase in cyberloafing behavior score. 


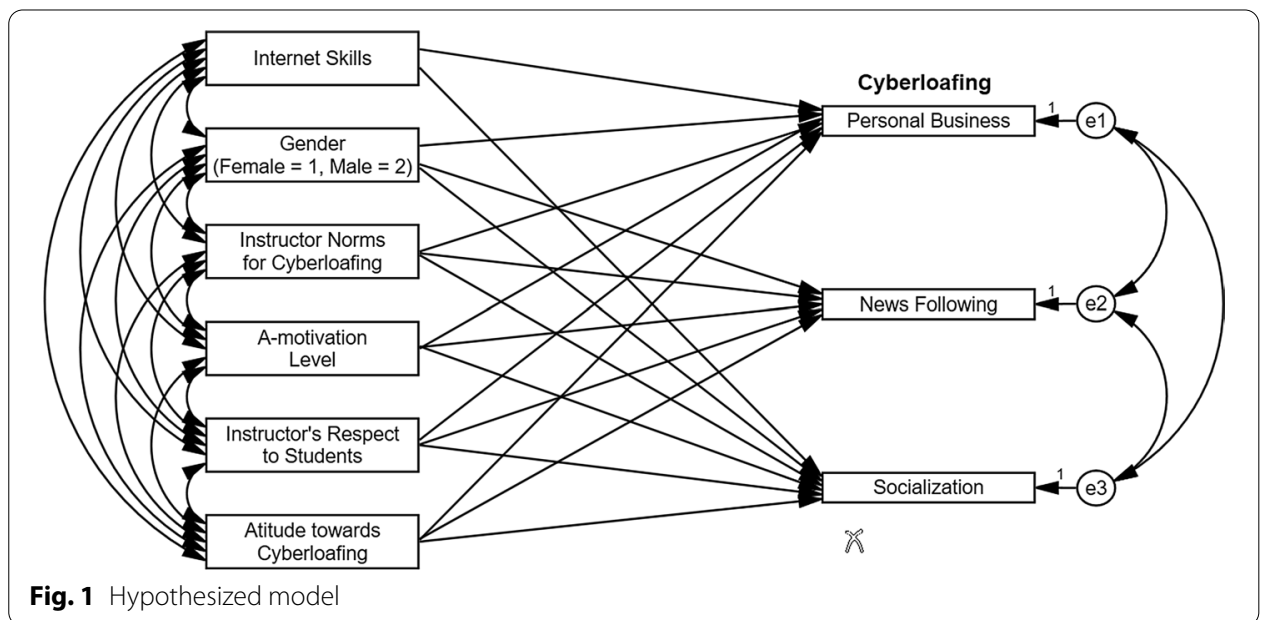

Fig. 1 Hypothesized model

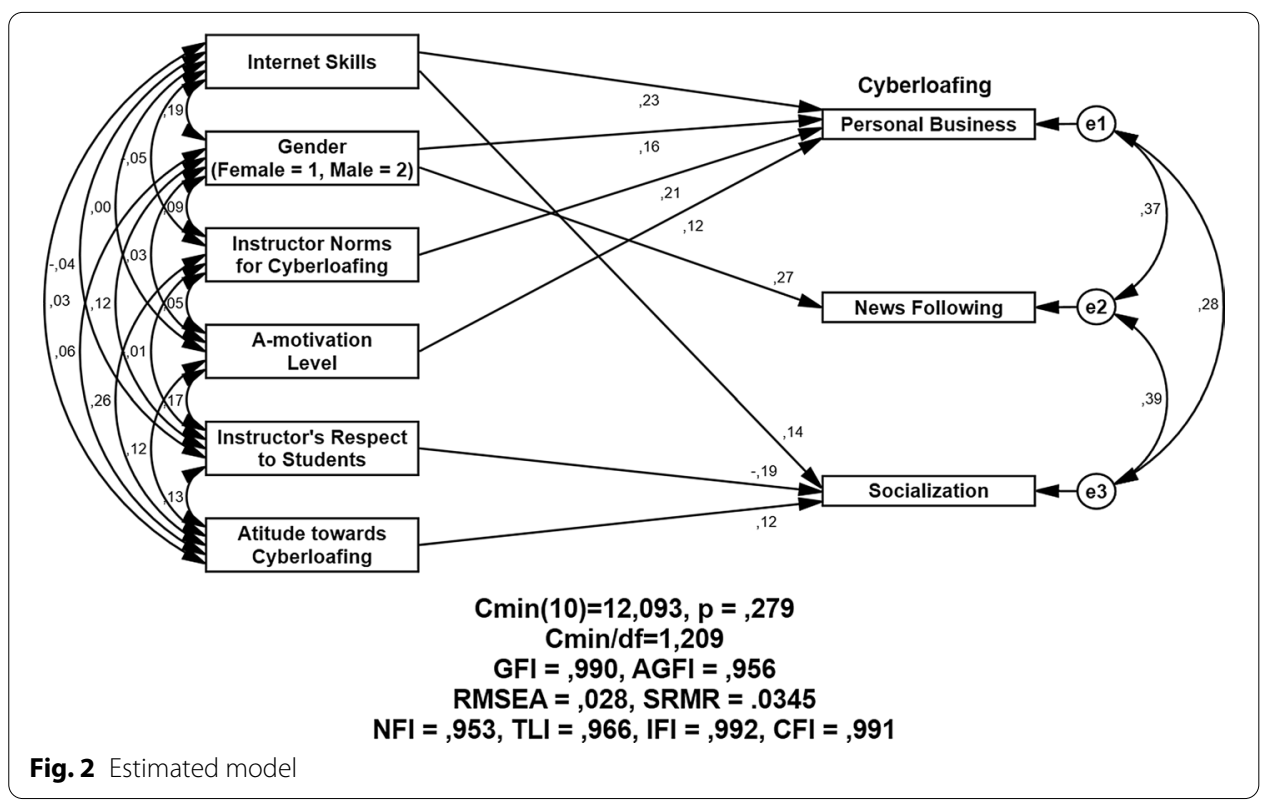

\section{The impact of demographic, psychological, and academic factors on different types of cyberloafing}

Figure 1 provides an illustration of the relationships between the individual factors included in the hypothesized model and the three sub-scales of cyberloafing. A thorough analysis of the data demonstrated significant associations between internet skill level and cyberloafing for personal business and socialization; gender and cyberloafing for personal business and news follow-up; instructor norms and cyberloafing for personal business; amotivation level and cyberloafing for personal business; instructor respect for students and cyberloafing for socialization; and student attitude towards cyberloafing and cyberloafing for socialization. Based on these findings, a new model was developed that excluded non-significant relationships. The standard estimates of the final model are included in Fig. 2. 
As Fig. 2 shows, internet skill level had a somewhat higher effect on cyberloafing for personal business than for socialization. Specifically, in computer lab teaching settings, students with higher internet skills tended to cyberloaf mostly for personal business, but also for socialization. In terms of gender, males tended to cyberloaf for personal business and news follow-up more than women, with a greater gender difference observed in news follow-up cyberloafing. Both a lack of instructor norms and student amotivation were associated with cyberloafing for personal business, but not with other forms of cyberloafing. When students were amotivated and instructor norms for cyberloafing were lacking, students would cyberloaf for personal business. Cyberloafing for socialization was affected by both instructor respect for students and student attitude towards cyberloafing. Whereas cyberloafing for socialization tended to increase with more positive student attitudes towards cyberloafing, it tended to decrease in connection with an increase in instructor respect for students.

Table 4 presents an evaluation of the fit indices of the model used to estimate the impact of all variables on specific types of cyberloafing behavior. Given that all the values were found to meet the special fit index criteria mentioned in the literature, the model can be considered valid for describing the study sample.

\section{Discussion}

Despite the existence of a theoretical framework and numerous studies on cyberloafing in work settings, studies in educational settings are scarce. The present study attempted to take the theoretical framework developed by Van Doorn (2011) specifically for work settings and adapt it to educational settings. In this regard, instructor norms and respect for students were examined rather than supervisor norms to represent organizational policies, and in place of job resources, a construct that is not described in detail in Van Doorn's theory, motivation was investigated as a resource-related construct in an educational setting. In addition to demographic characteristics, which included gender as well as factors related to internet-usage, sense of belonging and locus of control were examined as possible individual antecedents to cyberloafing, and attitudes towards cyberloafing and loafing were examined along with cyberloafing activities and behaviors.

The final model developed included six factors identified as being associated with cyberloafing behavior. Internet skill level had the greatest impact, followed by gender,

Table 4 Evaluation of model fit indices

\begin{tabular}{llll}
\hline Fit index & Model value & Criteria for perfect fit & Resource \\
\hline$X^{2}(3)$ & 12.093 and $p=0.279$ & Low $x^{2}$ value and $p>0.05$ & Hooper et al. (2008) \\
$X^{2} / d f$ & 1.209 & $x^{2} / d f<3$ & Wheaton et al. (1977), Tabachnick and Fidell (2007) \\
RMSEA & 0.028 & RMSEA $<0.05$ & Hu and Bentler (1999), Steiger (2007) \\
SRMR & 0.0345 & SRMR $\leq 0.05$ & Byrne (1998), Diamantopoulos and Siguaw (2000) \\
GFI & 0.990 & $0.95 \leq \mathrm{GFI} \leq 1$ & Tabachnick and Fidell (2007), Miles and Shevlin \\
AGFI & 0.956 & $0.85 \leq \mathrm{AGFI} \leq 1$ & (2007) \\
CFI & 0.991 & $2.97 \leq \mathrm{CFI} \leq 1$ & Tabachnick and Fidell (2007) \\
IFI & 0.992 & $0.95 \leq \mathrm{FI} \leq 0.95$ & Miles and Shevlin (2007) \\
NNFI & 0.953 & $0.97 \leq \mathrm{NNFI} \leq 1$ & Hu and Bentler (1999), Fan et al. (1999) \\
\hline
\end{tabular}


instructor respect for students, instructor norms regarding classroom cyberloafing, student amotivation, and student attitude towards cyberloafing. The remaining factors examined had no demonstrable effect on cyberloafing behavior.

The finding that increases in internet skill levels are accompanied by increases in cyberloafing behavior is not surprising and has been demonstrated by several previous studies (Arabaci, 2017; Baturay \& Toker, 2015; Blanchard \& Henle, 2008). However, whereas previous studies demonstrated a uniform effect on cyberloafing, the current study found cyberloafing for personal business and socialization to be affected more than cyberloafing for news follow-up (Arabaci, 2017; Baturay \& Toker, 2015). Internet experience and frequency of use were also analyzed as potential factors involved in cyberloafing, but no associations were identified.

Previous studies have highlighted the fact that cyberloafing behavior is more frequent among men than women (Baturay \& Toker, 2015; Dursun et al., 2018; Hargittai \& Shafer, 2006; Lim \& Chen, 2012; Vitak et al., 2011; Yllmaz et al., 2015). The present study supports this assumption. Moreover, when types of cyberloafing are examined in detail, it becomes clear that men and women exhibit different patterns of cyberloafing behavior. For example, this study found that males tend to spend more time cyberloafing for personal business and news follow-up, which is in line with a previous study (Baturay \& Toker, 2015). Cyberloafing for socialization, gaming and gambling, and shopping (Akbulut et al., 2017; Andreassen et al., 2014; Dursun et al., 2018) have also been reported to occur more frequently among men than women; however, according to Arabac1 (2017), cyberloafing for news follow-up is more common among women. While it appears that there are differences in the cyberloafing behavior of men and women, more research is required to understand these differences in detail.

Similar to Van Doorn's findings for organizational antecedents, this study found instructor norms in computer lab settings to be associated with decreases in cyberloafing. This is in line with the literature that states the presence of norms, whether those of managers in a work setting or instructors in an educational setting, is associated with decreased cyberloafing. With regard to work settings, Anandarajan and Simmers (2004) demonstrated that supervisor norms may affect cyberloafing in general, and Blanchard and Henle (2008) reported a more specific association between supervisor norms and minor cyberloafing, such as checking and sending non-workrelated emails; visiting news, financial and sports sites; shopping online; and participating in online auctions. In an educational setting, the literature suggests that classroom management, monitoring and controlling processes may prevent cyberloafing (Blanchard \& Henle, 2008; Dursun et al., 2018; Henle et al., 2009; de Lara et al., 2006).

Although norms may play a large role in determining cyberloafing behavior, this construct needs to be examined with great care in relation to short-term versus longterm impact. Establishing overly harsh norms carries with it the huge potential of generating unintended mild or severe consequences, including amotivation, dissatisfaction, sabotage and espionage as forms of payback. The enforcement of harsh rules with harsh punishment has been shown to have a negative effect on individuals (Lim, 2002; de Lara et al., 2006). According to Ugrin et al. (2018). Cyberloafing may function as a form of revenge behavior in response to disciplinary action, as individuals 
justify their cyberloafing behavior as a legitimate response to punishment and a means of balancing power.

It should also be noted that cyberloafing may be a behavior used to cope with stress (Lim \& Chen, 2012), regain energy (Bridegan, 2008) and support creativity (Oravec, 2002). While some managers feel that employees should never engage in personal use of the web at work, others believe this can help employees maintain balance in their lives. Striking a balance in the implementation of norms that falls somewhere between that of cyber-bureaucrats, who belief in strict adherence to all norms, and cyber-humanists, who recognize that cyberloafing can help individuals recover from emotional and physical exhaustion (Van Doorn, 2011), may help to avoid the adverse "payback" effects mentioned above.

According to Yllmaz and Yurdugül (2018), student cyberloafing may be an attempt at behavior that balances a perceived lack of respect on the part of instructors as well as strict instructor norms against cyberloafing. A similar situation has been observed in work settings where job demands exceed job resources (Lim, 2002; Robinson \& Bennett, 1995). Under such circumstances, cyberloafing may become a deviant behavior used to avoid an unpleasant situation (Van Doorn, 2011). Cyberloafing activities and behaviors that are triggered and/or legitimized by an unpleasant situation can spread rapidly among students. In other words, when instructors do not show respect for their students, their students may respond by cyberloafing in their classes.

Studies have reported that students will start to engage in cyberloafing when they lose motivation and interest and are unable to concentrate on their lessons (Sana et al., 2013; Yllmaz \& Yurdugül, 2018). In line with these findings, the current study found amotivation to be associated with increased cyberloafing, especially for personal business. It is possible that amotivation and cyberloafing behavior both increase when students are unsure about why they are attending university and don't see potential benefits of their education. Interestingly, no other types of motivation (intrinsic, integrated, introjected) were associated with cyberloafing, either positively or negatively. As Yllmaz and Yurdugül (2018) note, motivation is a complicated construct that may be indirectly affected by numerous factors, including classroom setting and atmosphere, attitude, and teaching and learning strategies. An example of this complicated interaction can be found in Barry et al. (2015), in which students gave the need to pay attention during a limited amount of class time, particularly when the lesson was demanding, as the reason for not using mobile phones during their lessons.

Conversely, students may use cyberloafing to increase their motivation and interest as well as their ability to concentrate on a lesson. Bridegan (2008) suggested that students may cyberloaf with the sole aim of clearing their minds while performing a task, which is similar to Wagner et al.s (2012) claim that cyberloafing in a work setting may help decrease an individual's mental workload and provide cognitive relaxation. This seems to contradict Van Doorn's (2011) model with regard to the negative effects of demandresource imbalances on well-being and motivation, but it is in line with the suggestion that cyberloafing should be tolerated to a certain extent (Yılmaz \& Yurdugül, 2018). Based on the findings of the present study, it is impossible to state that convincingly that amotivated students are likely to cyberloaf and motivated students are not; however, the 
findings do provide preliminary evidence for a relationship between cyberloafing and amotivation, which may indeed be a reciprocal relationship.

The current study also confirmed the literature stating that a positive attitude towards cyberloafing has an effect on cyberloafing behavior in an educational setting (Knight, 2017; Soh et al., 2018; Yllmaz \& Yurdugül, 2018). According to Ajzen (1991), student attitudes towards cyberloafing influence their intention to cyberloaf, which in turn influences their behavior, and several studies have demonstrated an association between attitude and intention to cyberloaf in workplace situations (Askew et al., 2014; Moody \& Siponen, 2013; Pee et al., 2008). In the present study, a positive attitude towards cyberloafing was found to be associated specifically with cyberloafing for socialization, but not with cyberloafing for personal business or news follow-up. It is possible that the attitude towards cyberloafing stimulates the intention to perform cyberloafing for socialization, which then leads to cyberloafing behavior, but further studies are required to clarify this assumption.

Whereas sense of belonging and external locus of control were associated with increased cyberloafing in work settings (Blanchard \& Henle, 2008; Van Dick, Tissington, et al., 2009), and the personal traits of conscientiousness, extraversion, honesty, and agreeableness were associated with decreased cyberloafing in both traditional and distance work settings (O'Neill et al., 2014; Van Doorn, 2011; Wyatt \& Phillips, 2005), the present study found no evidence that these factors had any predictive value in determining cyberloafing behavior in an educational setting. This may be due to certain difference between educational and work settings.

Finally, this study found no relationship between loafing and cyberloafing, which may have to do with the age of the study population. As discussed by Van Doorn (2011), loafing may be more specific to older individuals, who may take coffee breaks, smoke, read newspapers, or talk on the phone rather than engage in cyberloafing. While it is possible that age may explain the difference between loafing and cyberloafing, it is also possible that technological skill level plays a role. Younger individuals tend to have greater technological competence than older individuals, and an increase in cyberloafing in conjunction with an increase in internet skill level was noted in this study.

\section{Implications for practice}

The current study provides valuable clues on how cyberloafing can be monitored and exploited to improve student motivation. First, instructors need to establish clear rules for internet usage in computer-based classroom settings, but these rules need to be flexible enough to allow students to take advantage of cyberloafing to relax and eliminate their mental stress loads. Instructors should keep in mind that if students feel they are respected, they will be less likely to cyberloaf and more likely to pay attention to lectures. In order to maintain student interest, instructors can provide extra responsibilities to students who may be more inclined to perform cyberloafing, such as male students with high internet skill levels and low levels of motivation.

Students who are proficient internet users are especially prone to cyberloafing-and they may need to be reminded that, as the saying goes, "With great powers come great responsibilities." Here, we might adapt another saying-"Drink Responsibly," which is aimed at preventing drunk driving - to "Use Responsibly," in order to prevent a different 
type of deviant behavior, cyberloafing. An effective training program that focuses on the negative consequences of cyberloafing and warns students about ineffective and inefficient use of technology during class hours (Soh et al. 2018) could be included in an "ethics in computing curriculum", and development of such a comprehensive training program could be the subject of future design-based research studies.

\section{Limitations of the study}

This study has a number of limitations associated with the sample design. Data was collected using an online questionnaire, which represents a type of convenience sampling rather than random sampling; therefore, the study findings cannot be generalized. While purposive and convenience sampling strategies are unable to represent the population due to lack of randomness, their use is fairly common in educational research, where constraints such as time, money, and resources make random sampling infeasible (Wallen \& Fraenkel, 2001).

Another limitation in connection with the online survey methodology used is that it relied on self-selection by participants, and thus a non-response rate cannot be calculated (Thompson et al., 2003). For this reason, characteristics of respondents and nonrespondents cannot be compared (Guerra, 2003), making inherent bias in the study sample unavoidable (Leigh \& Tracey, 2010).

Finally, the self-reported nature of the survey data represents another limitation. Selfreport surveys are considered appropriate when individuals' personal experiences and opinions are the main emphasis of research ("Self-Report Method.," 2008). Self-reported data is presumed to provide a picture of the actual feelings and opinions of study participants; however, the confidential, anonymous nature of self-reporting makes data verification impossible (Witucki, 2006).

As Wright (2005) has stated, proper sampling is one of the major obstacles of survey research and has an impact on generalization. Future studies may attempt to collect data from different study populations and use larger sample sizes, and, if random sampling is possible, the study findings will then be generalizable to the wider population.

\section{Conclusion}

The current study examined various factors that could affect cyberloafing in an educational setting, namely a computer laboratory lecture class. Internet skills, gender (male), lack of instructor norms regarding cyberloafing, student amotivation and positive attitudes towards cyberloafing were associated with increases in cyberloafing behavior, whereas instructor respect for students was associated with decreases in cyberloafing behavior. When specific types of cyberloafing were examined, the study found internet skill level, gender, instructor norms and amotivation to be associated with cyberloafing for personal business; gender, instructor norms and amotivation to be associated with cyberloafing for news follow-up; and internet skill level, instructor respect for students, and student attitudes towards cyberloafing to be associated with cyberloafing for socialization. Considering the negative outcomes that may be associated with cyberloafing, future studies should be conducted that look at cyberloafing in different educational settings (e.g., in-person vs online learning) line and using different devices (e.g., mobile 
phones and tablets vs computers) in order to develop more effective interventions for limiting cyberloafing.

As noted by Varol and Yildırım (2019), educators will be able to provide more effective learning environments for their learners when they are able to establish more effective methods for preventing cyberloafing. In this regard, a number of areas can be suggested for future research to obtain additional data that can be used to extend and validate the model for educational settings developed by the present study.

First, the model developed by Von Doorn (2011) for work settings that formed the basis of this study can be explored in different types of educational settings, including both live lectures and online classes. The various gender differences identified in this study can be further researched to include clustering gender-specific cyberloafing behaviors performed by either men, women, or both genders. Interactions between "internet skill level" and other constructs can also be investigated to provide a more detailed understanding of the mechanisms affecting different types of cyberloafing.

Considering that rules and punishment may actually encourage behavior as well as encourage it, an eclectic composite of instructors that include both cyber-bureaucrats and cyber-humanists may be included in future studies to identify the direction and magnitude of the association between cyberloafing and instructor norms/institutional policies. In this regard, studies may investigate the effects of different strategies for instituting norms. Similarly, since instructor respect for students was identified as another factor influencing cyberloafing, its positive impact on cyberloafing should be examined in the future.

Motivation and cyberloafing may have a reciprocal relationship, with amotivation leading to cyberloafing on the other hand, and cyberloafing being used to relax and regain motivation on the other. Future studies may examine both aspects of this relationship. Finally, as noted above, future studies should investigate the potential of attitude towards cyberloafing to excite intention as well as actual behavior, especially with regard to cyberloafing for socialization.

Acknowledgements

There is no acknowledgement for this manuscript

\section{Authors' contributions}

ST carried out the data instrument preparation, data collection, data analysis, and reporting of the findings. Moreover, ST wrote the Theoretical Framework, Method, Results sections, and contributed to Discussion and Conclusion sections. MHB wrote Introduction, Literature Review, and contributed to Discussion and Conclusion sections. Both ST and MHB participated in the overall arrangement of all progressing drafts. Both authors read and approved the final manuscript.

Funding

This study received no funding

Availability of data and materials

The study data is available upon request.

Competing interests

The authors declare that they have no competing interests.

Author details

1 Information Systems Engineering Department, School of Engineering, Atilim University, Kizilcasar Mah., Golbasi, Ankara

Turkey. ${ }^{2}$ Center for Teaching and Learning, Atilim University, Kizilcasar Mah., Golbasi, Ankara, Turkey.

Received: 1 October 2020 Accepted: 28 February 2021

Published online: 26 March 2021 


\section{References}

Ajzen, I. (1985). From intentions to actions: A theory of planned behavior. In Action control (pp. 11-39). Springer, Berlin. Ajzen, I. (1991). The theory of planned behavior. Organizational Behavior and Human Decision Processes, 50(2), 179-211. Akbulut, Y., Dönmez, O., \& Dursun, Ö. Ö. (2017). Cyberloafing and social desirability bias among students and employees. Computers in Human Behavior, 72, 87-95.

Akbulut, Y., Dursun, Ö. ̈̈., Dönmez, O., \& Şahin, Y. L. (2016). In search of a measure to investigate cyberloafing in educational settings. Computers in Human Behavior, 55, 616-625.

Akgün, F. (2020). Investigation of high school students' cyberloafing behaviors in classes. Education \& Science, 45(201), 79-108.

Anandarajan, M., \& Simmers, C. A. (2004). Constructive and dysfunctional personal web usage in the workplace: mapping employee attitudes. In Personal web usage in the workplace: A quide to effective human resources management (pp. 1-27). IGI Global.

Andreassen, C. S., Torsheim, T., \& Pallesen, S. (2014). Predictors of use of social network sites at work: A specific type of cyberloafing. Journal of Computer-Mediated Communication, 19(4), 906-921.

Anwaruddin, S. M. (2013). Web 2.0 and language learners' motivation: an action research study. The Canadian Journal of Action Research, 14(1), 51-68.

Arabaci, I. B. (2017). Investigation faculty of education students' cyberloafing behaviors in terms of various variables. Turkish Online Journal of Educational Technology-TOJET, 16(1), 72-82.

Askew, K., Buckner, J. E., Taing, M. U., Ilie, A., Bauer, J. A., \& Coovert, M. D. (2014). Explaining cyberloafing: The role of the theory of planned behavior. Computers in Human Behavior, 36, 510-519.

Askew, K., Coovert, M. D., Vandello, J. A., Taing, M. U., \& Bauer, J. A. (2011). Work environment factors predict cyberloafing. Poster presented at the Annual Meeting of the Association for Psychological Science. Washington DC.

Bacanlı, H., Illhan, T. \& Aslan, S. (2009). Beş faktör kişilik kuramına dayalı bir kişilik ölçeğinin geliştirilmesi: Sıfatlara Dayalı Kişilik Testi. [Development of A Personality Scale Based on Five Factor Theory: Adjective Based Personality Test (ABPT)]. Türk Eğitim Bilimleri Dergisi, 7(2), 261-279. Retrieved from https://dergipark.org.tr/en/pub/tebd/issue/ 26107/275060.

Barry, S., Murphy, K., \& Drew, S. (2015). From deconstructive misalignment to constructive alignment: Exploring student uses of mobile technologies in university classrooms. Computers \& Education, 81, 202-210.

Baturay, M. H., \& Toker, S. (2015). An investigation of the impact of demographics on cyberloafing from an educational setting angle. Computers in Human Behavior, 50, 358-366.

Beck, A. T., Steer, R. A., \& Carbin, M. G. (1988). Psychometric properties of the Beck Depression Inventory: Twenty-five years of evaluation. Clinical Psychology Review, 8(1), 77-100.

Belanger, F. \& van Slyke, C. (2002). Abuse or learning? Communications of the ACM, 45, 64-65.

Bentler, P. M., \& Chou, C. P. (1987). Practical issues in structural modeling. Sociological Methods \& Research, 16(1), 78-117.

Blanchard, A. L., \& Henle, C. A. (2008). Correlates of different forms of cyberloafing: The role of norms and external locus of control. Computers in Human Behavior, 24, 1067-1084.

Bollen, K. A. (1989). A new incremental fit index for general structural equation models. Sociological Methods \& Research, 17(3), 303-316.

Boomsma, A. (1985). Nonconvergence, improper solutions, and starting values in LISREL maximum likelihood estimation. Psychometrika, 50(2), 229-242.

Bridegan, G. L. (2008). Take a break from WMDs. ISHN, 42(2), 51.

Brown-Wright, L., Tyler, K. M., Graves, S. L., Thomas, D., Stevens-Watkins, D., \& Mulder, S. (2013). Examining the associations among home-school dissonance, amotivation, and classroom disruptive behavior for urban high school students. Education and Urban Society, 45(1), 142-162.

Brubaker, A. T. (2006). Faculty perceptions of the impact of student laptop use in a wireless Internet environment on the classroom learning environment and teaching (Master's Thesis) Chapel Hill: University of North Carolina. Retrieved October 18, 2019 from https://pdfs.semanticscholar.org/fdfd/0b742c1782e708d3e16b2a42cc11e5308b67.pdf.

Burger, M. J. (2006). Kişilik [Personality] (çev. İ. D. Erguvan Sarıoğlu). İstanbul: Kaknüs Yayınları.

Burnett, G., \& Walz, G. (1994). Gangs in the schools (Rep. No. EDO-CG94-28). Greensboro, NC: ERIC Clearinghouse on Counseling and Student Services.

Byrne, B. M. (1998). Structural equation modeling with LISREL, PRELIS and SIMPLIS: Basic concepts, applications and programming. Mahwah, New Jersey: Lawrence Erlbaum Associates.

Cano-García, F. J., Padilla-Muñoz, E. M., \& Carrasco-Ortiz, M. Á. (2005). Personality and contextual variables in teacher burnout. Personality and Individual Differences, 38(4), 929-940.

Cheon, S. H., \& Reeve, J. (2015). A classroom-based intervention to help teachers decrease students' amotivation. Contemporary Educational Psychology, 40, 99-111.

Costa, P. T., \& McCrae, R. R. (1992). Revised NEO personality inventory (NEO PI-R) and NEO five-factor inventory (NEO-FFI): Professional manual. Psychological Assessment Resources, Incorporated.

Costa, P. T., \& McCrae, R. R. (2011). The five-factor model, five-factor theory, and interpersonal psychology. In Handbook of interpersonal psychology: Theory, research, assessment, and therapeutic interventions (pp. 91-104).

Costa, P.T., Jr., McCrae, R. R., \& Kay, G. G. (1995). Persons, places, and personality: Career assessment using the Revised NEO Personality Inventory. Journal of Career Assessment, 3(2), 123-139.

Creswell, J. W. (2012). Educational research: Planning, conducting, and evaluating quantitative and qualitative research (Vol. 4). Pearson.

Cüceloğlu, D. (1996). Inssan ve davranışı (7. Baskı). İstanbul: Remzi Kitabevi.

Dağ, I. (1991). Rotter'in Iç-Dış Kontrol Odağı Ölçeği (RiDKOÖ)'nin üniversite öğrencileri için güvenirliği ve geçerliği [Validity and reliability of Rotter's Internal-External Locus of Control Scale for University Students ]. Psikoloji Dergisi, 7(26), $10-16$.

Deci, E., \& Ryan, R. M. (2002). Overview of self-determination theory: An organismic dialectical perspective. In E. L. Deci \& R. M. Ryan (Eds.), Handbook of self-determination research (pp. 3-33). University of Rochester Press. 
De Jonge, J., \& Dormann, C. (2006). Stressors, resources, and strain at work: a longitudinal test of the triple-match principle. Journal of Applied Psychology, 91(6), 1359.

de Lara, P. Z. M., Tacoronte, D. V., \& Ding, J. M. T. (2006). Do current anti-cyberloafing disciplinary practices have a replica in research findings? A study of the effects of coercive strategies on workplace Internet misuse. Internet Research.

Demirci, E. (2004). Evlilikte bağlanma ve çatışmayı yönetmede bağlanma stillerinin etkisi. Yayımlanmamış Yüksek Lisans Tezi, Karadeniz Teknik Üniversitesi, Sosyal Bilimler Enstitüsü, Trabzon [Attachment in marriage and affects of attachment style in management of confliction.] Unpublished Master's Thesis, Karadeniz Technical University, Institute of Social Sciences, Trabzon.

Diamantopoulos, A., \& Siguaw, J. A. (2000). Introducing LISREL. London: Sage Publications.

Durak, H. Y. (2019). Cyberloafing in learning environments where online social networking sites are used as learning tools: Antecedents and consequences. Journal of Educational Computing Research. https://doi.org/10.1177/0735633119 867766

Dursun, O., Donmez, O., \& Akbulut, Y. (2018). Predictors of cyberloafing among preservice information technology teachers. Contemporary Educational Technology, 9(1), 22-41.

Estapa, A., \& Nadolny, L. (2015). The effect of an augmented reality enhanced mathematics lesson on student achievement and motivation. Journal of STEM education, 16(3).

Fan, X., Thompson, B., \& Wang, L. (1999). Effects of sample size, estimation methods, and model specification on structural equation modeling fit indexes. Structural Equation Modeling, 6(1), 56-83.

Fishbein, M., \& Ajzen, I. (1975). Belief, attitude, intention, and behavior: An introduction to theory and research. AddisonWesley. Retrieved from http://people.umass.edu/aizen/f\&a1975.html.

Fried, C. (2008). In-class laptop use and its effects on student learning. Computers \& Education, 50(3), 906-914.

Gençöz, T. (2000). Pozitif ve negatif duygu ölçeği: Geçerlik ve güvenirlik çalışması. [Positive and negative affect schedule: A study of validity and reliability]. Türk Psikoloji Dergisi, 15(46), 19-26.

Gerow, J. E., Galluch, P.S. \& Thatcher, J.B. (2010). To slack or not to slack: Internet usage in the classroom, Journal of Information Technology: Theory and Implication, 11 (3), article 2, Retrieved March 25, 2019 from https://www.ojphi.org/ojs/ index.php/fm/article/view/7837/7417.

Goldberg, L. R. (1993). The structure of phenotypic personality traits. American Psychologist, 48(1), 26.

Goodenow, C., \& Grady, K. E. (1993). The relationship of school belonging and friends'values to academic motivation among urban adolescent students. The Journal of Experimental Education, 62(1), 60-71.

Guerra, I. J. (2003). Key competencies required of performance improvement professionals. Performance Improvement Quarterly, 16(1), 55-72

Hargittai, E., \& Shafer, S. (2006). Differences in actual and perceived online skills: The role of gender. Social Science Quarterly, 87(2), 432-448.

Hastings, S. E., \& O'Neill, T. A. (2009). Predicting workplace deviance using broad versus narrow personality variables. Personality and Individual Differences, 47, 289-293.

Henle, C. A., \& Blanchard, A. L. (2008). The interaction of work stressors and organizational sanctions on cyberloafing. Journal of Managerial Issues, 383-400.

Henle, C. A., Kohut, G., \& Booth, R. (2009). Designing electronic use policies to enhance employee perceptions of fairness and to reduce cyberloafing: An empirical test of justice theory. Computers in Human Behavior, 25(4), 902-910.

Hobfoll, S. E. (2001). The influence of culture, community, and the nested-self in the stress process: Advancing conservation of resources theory. Applied Psychology: An International Review, 50, 337-421.

Hooper, D., Coughlan, J., \& Mullen, M. (2008). Structural equation modelling: guidelines for determining model fit. Electronic Journal of Business Research Methods, 6(1), 53-60.

$\mathrm{Hu}$, L. T., \& Bentler, P. M. (1999). Cutoff criteria for fit indexes in covariance structure analysis: conventional criteria versus new alternatives. Structural Equation Modeling, 6(1), 1-55.

Janssen, P. P. M., Peeters, M. C. W. de Jonge, J., Houkes, I., \& Tummers, G. E. R. (2004). Specific relationships between job demands, job resources and psychological outcomes and the mediating role of negative work-home interference. Journal of Vocational Behaviour, 65, 411-429.

Jones, F., \& Fletcher, B. (1996). Job control and health. In M. J. Schabracq, J. A. M. Winnubst, \& C. L. Cooper (Eds.), Handbook of work and health psychology (pp. 33-50). Wiley.

Kalanzadeh, G. A., Soleimani, H., \& Bakhtiarvand, M. (2014). Exploring the influence of using technology on Iranian EFL students' motivation. Procedia-Social and Behavioral Sciences, 98, 814-823.

Kalaycı, E. (2010). Üniversite öğrencilerinin siber aylaklık davranışları ile özdüzenleme stratejileri arasındaki ilişkinin incelenmesi [Investigation of relationship between cyberloafing and self-regulated learning strategies among undergraduate students] (Unpublished doctoral dissertation). Ankara: Hacettepe Üniversitesi/Fen Bilimleri Enstitüsü.

Kara, A. (2008). Illköğretim birinci kademede eğitimde motivasyon ölçeğinin Türkçeye uyarlanması. [Adaptation of the "Echelle de Motivation en Education"Scale to Turkish]. Ege Ë̆itim Dergisi, 9(2), 59-78.

Kember, D., Lee, K., \& Li, N. (2001). Cultivating a sense of belonging in part-time students. International Journal of Lifelong Education, 20(4), 326-341.

Keser, H., \& Teker, N. (2011). The study of developments in computer education in Turkey between 1960-1988. Ilkogretim Online, 10(3), 1010-1027.

Kline, P. (1998). The new psychometrics: Science, psychology, and measurement. London, UK: Routledge.

Knight, R. M. (2017). Academic cyberloafing: a study of perceptual and behavioral differences on in-class cyberloafing among undergraduate students. Unpublished Master's Thesis. East Carolina University.

Krishnan, S., Lim, V. K., \& Teo, T. S. (2010). How does personality matter? Investigating the impact of big-five personality traits on cyberloafing. Paper presented at the ICIS, (p. 6).

Kurland, N. B., \& Bailey, D. E. (1999). When workers are here, there, and everywhere: A discussion of the advantages and challenges of telework. Organizational Dynamics, 28(2), 53-58.

Legault, L., Green-Demers, I., \& Pelletier, L. (2006). Why do high school students lack motivation in the classroom? Toward an understanding of academic amotivation and the role of social support. Journal of Educational Psychology, 98(3), 567. 
Leigh, H. N., \& Tracey, M. W. (2010). A review and new framework for instructional design practice variation research. Performance Improvement Quarterly, 23(2), 33-46.

Li, S., \& Chung, T. (2006). Internet function and Internet addictive behaviour. Computers in Human Behaviour, 22, 1067-1071.

Liberman, B., Seidman, G., Mckenna, K. Y., \& Buffardi, L. E. (2011). Employee job attitudes and organizational characteristics as predictors of cyberloafing. Computers in Human Behavior, 27(6), 2192-2199.

Lim, V. K. (2002). The IT way of loafing on the job: Cyberloafing, neutralizing and organizational justice. Journal of Organizational Behavior, 23(5), 675-694.

Lim, V. K. G., \& Chen, D. J. Q. (2012). Cyberloafing at the workplace: gain or drain on work? Behaviour \& Information Technology, 31(4), 343-353.

Lim, V. K., \& Teo, T. S. (2005). Prevalence, perceived seriousness, justification and regulation of cyberloafing in Singapore: An exploratory study. Information \& Management, 42(8), 1081-1093.

Loehlin, J. C. (1992). Genes and environment in personality development. Sage Publications Inc.

MacCallum, R. C., Browne, M. W., \& Sugawara, H. M. (1996). Power analysis and determination of sample size for covariance structure modeling. Psychological Methods, 1(2), 130.

MacKinnon, G. R., \& Vibert, C. (2002). Judging the constructive impacts of communication technologies: A business education study. Education and Information Technologies, 7(2), 127-135.

McLean, L., Tingley, M., Scott, R. N., \& Richards, J. (2001). Computer terminal work and the benefit of micro breaks. Applied Ergonomics, 32, 225-237.

Miles, J., \& Shevlin, M. (2007). A time and a place for incremental fit indices. Personality and Individual Differences, 42(5), 869-874.

Moody, G. D., \& Siponen, M. (2013). Using the theory of interpersonal behavior to explain non-work-related personal use of the internet at work. Information \& Management, 50(6), 322-335.

Mulvey, P. W., \& Klein, H. J. (1998). The impact of perceived loafing and collective efficacy on group goal processes and group performance. Organizational Behavior and Human Decision Processes, 74(1), 62-87.

Novikova, I. A. (2013). Big Five (the five-factor model and the five-factor theory). The Encyclopedia of Cross-Cultural Psychology, 1, 136-138.

Nunnally, J. C. (1967). Psychometric Theory. New York, N.Y.: McGraw-Hill.

O'Neill, T. A., Hambley, L. A., \& Bercovich, A. (2014). Prediction of cyberslacking when employees are working away from the office. Computers in Human Behavior, 34, 291-298.

Öner, L. ve Le Compte, A. (1998). "Durumluk ve Sürekli Kaygı Ölçeği El Kitabı" [Handbook of State-Trait anxiety inventory scale]. İstanbul Boğaziçi Üniversitesi Yayınları 2. Baskı.

Oravec, J. A. (2002). Constructive approaches to Internet recreation in the workplace. Communications of the ACM, 45, 60-63.

Pee, L. G., Woon, I. M., \& Kankanhalli, A. (2008). Explaining non-work-related computing in the workplace: A comparison of alternative models. Information \& Management, 45(2), 120-130.

Pintrich, P. R., \& De Groot, E. V. (1990). Motivational and self-regulated learning components of classroom academic performance. Journal of Educational Psychology, 82, 33-40.

Pishghadam, R., \& Sahebjam, S. (2012). Personality and emotional intelligence in teacher burnout. The Spanish Journal of Psychology, 15(1), 227-236.

Pittman, L. D., \& Richmond, A. (2007). Academic and psychological functioning in late adolescence: The importance of school belonging. The Journal of Experimental Education, 75(4), 270-290.

Poropat, A. E. (2009). A meta-analysis of the five-factor model of personality and academic performance. Psychological Bulletin, 135(2), 322.

Prensky, M., \& Berry, B. D. (2001). Do they really think differently. On the Horizon, 9(6), 1-9.

Ravizza, S. M., Hambrick, D. Z., \& Fenn, K. M. (2013). Non-academic internet use in the classroom is negatively related to classroom learning regardless of intellectual ability. Computers \& Education, 78, 109-114.

Robinson, S. L., \& Bennett, R. J. (1995). A typology of deviant workplace behaviors: A multidimensional scaling study. Academy of Management Journal, 38(2), 555-572.

Rosenbaum, M. (1980). A schedule for assessing self-control behaviors: Preliminary findings. Behavior Therapy, 11(1), $109-121$.

Rotter, J. B. (1966). Generalized expectancies for internal versus external control of reinforcement. Psychological Monographs: General and Applied, 80(1), 1

Sana, F., Weston, T., \& Cepeda, N. J. (2013). Laptop multitasking hinders classroom learning for both users and nearby peers. Computers \& Education, 62, 24-31.

Saritepeci, M. (2019). Predictors of cyberloafing among high school students: unauthorized access to school network, metacognitive awareness and smartphone addiction. Education and Information Technologies, 25, 2201-2219.

Savaşır, I. ve Şahin, N. H. (1997). Bilişsel Davranış̧̧ Terapilerde Değerlendirme: Sık Kullanılan Ölçekler. [Assessment in Cognitive Behavioral Therapies: Frequently used Scales]. Türk Psikoloji Derneği Yayınları, No: 9.

Self-Report Method. (2008). International encyclopedia of the social sciences. Retrieved October 12, 2010, from http:// www.encyclopedia.com/doc/1G2-3045302394.html

Şenel, S., Günaydın, S., Sarıtaş, M. T., \& Çiğdem, H. (2019). The factors predicting cyberloafing behaviors of undergraduate students. Kastamonu Education Journal, 27(1), 95-105.

Sheikh, A., Aghaz, A., \& Mohammadi, M. (2019). Cyberloafing and personality traits: an investigation among knowledge-workers across the Iranian knowledge-intensive sectors. Behaviour \& Information Technology, 38(12), $1213-1224$.

Shi, M., \& Bichelmeyer, B. A. (2007). Teachers' experiences with computers: A comparative study. Journal of Educational Technology \& Society, 10(2), 180-190.

Sivrikova, N., Roslyakova, S., Sokolova, N., \& Moiseeva, E. (2019). Assessing of use of the Internet for personal reasons at lessons at school: A Validation of the Cyberloafing Scale. In SHS Web of Conferences (Vol. 70, p. 06010). EDP Sciences. 
Skolnik, R., \& Puzo, M. (2008). Utilization of laptop computers in the school of business classroom. Academy of Educational Leadership Journal, 12(2), 1-10.

Soh, P. C. H., Koay, K. Y., \& Lim, V. K. (2018). Understanding cyberloafing by students through the lens of an extended theory of planned behavior. First Monday, 23(6), Retrieved from March 21, 2019 from https://www.ojphi.org/ ojs/index.php/fm/article/view/7837.

Spielberger, C. D. (2010). State-Trait anxiety inventory. The Corsini encyclopedia of psychology, 1-1.

Steiger, J. H. (2007). Understanding the limitations of global fit assessment in structural equation modeling. Personality and Individual Differences, 42(5), 893-898.

Tabachnick, B. G., \& Fidell, L. S. (2007). Using Multivariate Statistics (5th ed.). New York: Allyn and Bacon.

Thompson, L. F., Surface, E. A., Martin, D. L., \& Sanders, M. G. (2003). From paper to pixels: Moving personnel surveys to the Web. Personnel Psychology, 56(1), 197-227.

Tindell, D. R., \& Bohlander, R. W. (2012). The use and abuse of cell phones and text messaging in the classroom: A survey of college students. College Teaching, 60, 1-9.

Ugrin, J. C., Pearson, J. M., \& Nickle, S. M. (2018). An examination of the relationship between culture and cyberloafing using the Hofstede model. Journal of Internet Commerce, 17(1), 46-63.

Vallerand, R. J., Pelletier, L. G., Blais, M. R., Briere, N. M., Senecal, C., \& ve Vallieres, E. F. (1992). The academic motivation scale: a measure of intrinsic, extrinsic, and amotivation in education. Educational, and Psychological Measurement, 52, 1003-1017.

Van Dick, R., Stellmacher, J., Wagner, U., Lemmer, G., \& Tissington, P. A. (2009). Group membership salience and task performance. Journal of Managerial Psychology, 24(7), 609-626.

Van Dick, R., Tissington, P. A., \& Hertel, G. (2009). Do many hands make light work? How to overcome social loafing and gain motivation in work teams. European Business Review, 21(3), 233-245.

Van Doorn, O. N., (2011). Cyberloafing: A multi-dimensional construct placed in a theoretical framework. Department Industrial Engineering and Innovation Sciences. Eindhoven University of Technology, Unpublished Master Thesis, Eindhoven: Netherlands.

Varghese, L., \& Barber, L. K. (2017). A preliminary study exploring moderating effects of role stressors on the relationship between Big Five personality traits and workplace cyberloafing. Cyberpsychology: Journal of Psychosocial Research on Cyberspace, $11(4)$.

Varol, F., \& Yıldırım, E. (2019). Cyberloafing in higher education: Reasons and suggestions from students' perspectives. Technology, Knowledge and Learning, 24(1), 129-142.

Vitak, J., Crouse, J., \& LaRose, R. (2011). Personal Internet use at work: Understanding cyberslacking. Computers in Human Behavior, 27, 1751-1759.

Wagner, D. T., Barnes, C. M., Lim, V. K., \& Ferris, D. L. (2012). Lost sleep and cyberloafing: Evidence from the laboratory and a daylight saving time quasi-experiment. Journal of Applied Psychology, 97(5), 1068.

Wallen, N. E., \& Fraenkel, J. R. (2001). Educational research: A guide to the process. Lawrence Erlbaum Associates Inc, Publishers.

Watson, D., Clark, L. A., \& Tellegen, A. (1988). Development and validation of brief measures of positive and negative affect: the PANAS scales. Journal of Personality and Social Psychology, 54(6), 1063.

Weatherbee, T. G. (2010). Counterproductive use of technology at work: Information \& communications technologies and cyberdeviancy. Human Resource Management Review, 20, 35-44.

Wheaton, B., Muthen, B., Alwin, D. F., \& Summers, G., (1977). Assessing reliability and stability in panel models. Sociological Methodology, 8(1), 84-136.

Wilson, K., Fornasier, S., \& White, K. M. (2010). Psychological predictors of young adults' use of social networking sites. Cyberpsychology, Behavior, and Social Networking, 13(2), 173-177.

Witucki, A. P. (2006). Factors affecting knowledge and usage of specific performance improvement interventions by novice and expert performance technologists (Ph.D. dissertation, Wayne State University, Detroit, Michigan, United States.) Retrieved from October 12, 2010, Dissertations \& Theses @ Wayne State University (Publication No. AAT 3210994)

Wright, K. B. (2005). Researching internet-based populations: advantages and disadvantages of online survey research, online questionnaire authoring software packages, and web survey services. Journal of ComputerMediated Communication, 10(3), 00-00. https://doi.org/10.1111/j.1083-6101.2005.tb00259.x

Wyatt, K., \& Phillips, J. G. (2005, November). Internet use and misuse in the workplace. In Proceedings of the 17th Australia conference on Computer-Human Interaction: Citizens Online: Considerations for Today and the Future (pp. 1-4).

Yaşar, S., \& Yurdugül, H. (2013). The investigation of relation between cyberloafing activities and cyberloafing behaviors in higher education. Procedia-Social and Behavioral Sciences, 83, 600-604.

Yılmaz, F. G. K., Yılmaz, R., Öztürk, H. T., Sezer, B., \& Karademir, T. (2015). Cyberloafing as a barrier to the successful integration of information and communication technologies into teaching and learning environments. Computers in Human Behavior, 45, 290-298.

Y.lmaz, R., \& Yurdugül, H. (2018). Cyberloafing in IT classrooms: exploring the role of the psycho-social environment in the classroom, attitude to computers and computing courses, motivation and learning strategies. Journal of Computing in Higher Education, 30(3), 530-552.

Young, K.S. (2010). Policies and procedures to manage employee Internet abuse. Computers in Human Behaviour, 1-5.

Zandvliet, D. B., \& Fraser, B. J. (2005). Physical and psychosocial environments associated with networked classrooms. Learning Environments Research, 8, 1-17.

Zoghbi Manrique de Lara, P. (2006). Fear in organizations: Does intimidation by formal punishment mediate the relationship between interactional justice and workplace internet deviance? Journal of Managerial Psychology, 21(6), 580-592.

\section{Publisher's Note}

Springer Nature remains neutral with regard to jurisdictional claims in published maps and institutional affiliations. 